\title{
Ocena jakościowo-ilościowa gazów pochodzących z degazacji rdzeni skalnych na tle właściwości petrofizycznych skał kompleksu miedzionośnego południowej części monokliny przedsudeckiej
}

\author{
Qualitative and quantitative evaluation of gases originating from the rock cores degassing \\ against the petrophysical properties of the rocks from copper-bearing complex of the \\ southern part of the Fore-Sudetic Monocline
}

\author{
Małgorzata Kania, Marek Janiga \\ Instytut Nafty i Gazu - Państwowy Instytut Badawczy
}

\begin{abstract}
STRESZCZENIE: Przedmiotem badań były próbki rdzeni pochodzące z utworów miedzionośnych, w celu określenia zależności różnego typu parametrów geochemicznych z wykształceniem litologicznym badanych skał w nawiązaniu do badań petrofizycznych. W związku z tym przeanalizowany został zarówno skład molekularny gazów pod kątem obecności azotu nadmiarowego, helu, wodoru, związków siarki i węglowodorów, jak również dokładna ilość wydzielonego gazu. Badania przeprowadzono na próbkach gazu desorbowanego oraz na próbkach gazu resztkowego i na tej podstawie zostały określone pewne prawidłowości zmian jakościowo-ilościowych, co w konsekwencji pozwala na przewidywanie lokalizacji miejsc o zwiększonej akumulacji dla poszczególnych gazów. Dodatkowo analizie statystycznej poddano wybrane właściwości petrofizyczne skał, z których pozyskano gaz. Na podstawie uzyskanych wyników badań można zaklasyfikować skały takie, jak piaskowiec i dolomit wapnisty, jako typy litologiczne o wysokim potencjale akumulacyjnym dla gazów. Zdecydowanie najwyższa ilość gazu resztkowego uzyskana została z serii piaskowców. Nieco mniejsze ilości gazu wydzieliły się z kolei z próbek dolomitu wapnistego. Jeszcze mniejsze zanotowano dla soli kamiennej, a najniższe dla próbek anhydrytowych. Średnie ilości wydzielonego gazu resztkowego doskonale korelują z właściwościami petrofizycznymi, takimi jak: średnie wartości porowatości całkowitej i otwartej, powierzchnia właściwa oraz przepuszczalność. Na podstawie przeprowadzonej analizy, zaobserwowano duże zróżnicowanie oznaczeń zarówno ilościowo-jakościowych gazów, jak i właściwości petrofizycznych badanych rdzeni piaskowców i dolomitów wapnistych (gdzie mogą być kumulowane duże ilości gazu, co stanowi zasadnicze zagrożenie dla wyrobisk górniczych). Z kolei dostępne wyniki badań dla próbek anhydrytowych oraz soli kamiennej sugerują, że w analizowanym obszarze (pomimo stosunkowo słabych właściwości kolektorskich skał) pojawiają się jednak warunki do wystąpienia lokalnych pułapek gazu w strefach o podwyższonej porowatości.
\end{abstract}

Słowa kluczowe: degazacja, gaz desorbowany, gaz resztkowy, chromatografia gazowa, skład molekularny, właściwości petrofizyczne, seria miedzionośna, LGOM.

ABSTRACT: The subject of the study were core samples originating from copper-bearing deposits, in order to determine the correlation of different types of geochemical parameters with the lithological variation of the studied rocks in reference to petrophysical investigations. The molecular gas composition for the presence of excess nitrogen, helium, hydrogen, sulfur compounds, and hydrocarbons, as well as the exact amount of evolved gas, were examined. The tests were performed on samples of desorbed gas and on residual gas samples, and on this basis certain regularities of qualitative and quantitative changes were determined, which in turn allows to forecast the location of places with increased accumulation of individual gases. Additionally, the petrophysical properties of the rocks from which the gas was obtained, were subjected to statistical analysis. Based on the obtained research results, rocks such as sandstone and calcareous dolomite can be classified as lithological types with high accumulation capacities for gases. It is clear that the highest amount of residual gas was obtained from a series of sandstones, slightly smaller amounts of gas released from the samples of calcareous dolomite; less were noted for rock salt, and the lowest for anhydrite samples. The average amount of separated residual gas perfectly correlates with the petrophysical properties, such as: mean values of total and open porosity, specific surface area, and permeability. On the basis of the analysis, a large diversity of quantitative and qualitative gas coposition determinations, and the petrophysical properties

Autor do korespondencji: M. Kania, e-mail: kaniam@inig.pl

Artykuł nadesłano do Redakcji 25.01.2019 r. Zatwierdzono do druku 13.05.2019 r. 
of the studied sandstone and dolomite cores was observed (where large amounts of gas can be accumulated, which is a major threat to mining excavations). In contrast, the available results for anhydrite and rock salt samples suggest that in the analysed area (despite the relatively poor collector properties of rocks), there are conditions for local gas traps in zones with increased porosity.

Key words: degassing, desorbed gas, residual gas, gas chromatography, molecular composition, petrophysical properties, copper-bearing series, Legnica-Głogów Copper District (LGOM).

\section{Wstęp}

Występowanie gazu ziemnego i ropy naftowej w utworach permu południowej części monokliny przedsudeckiej w rejonie Legnicko-Głogowskiego Okręgu Miedziowego (LGOM), stwierdzono już w latach 1962-1980, podczas prowadzenia wierceń badawczych z powierzchni (Downorowicz, 2007). Natomiast na początkowym etapie dokumentowania złóż rud miedzi, prowadzonego w obszarze między Lubinem i Sieroszowicami (Kłapciński i Peryt, 2007) zaobserwowano objawy zgazowania płuczki w kilkunastu wierconych wówczas otworach, które miały miejsce głównie w seriach: węglanowej (Ca1) i anhydrytowej (A1). Jednak faktycznie intensywne badania w obrębie zagospodarowanych złóż LGOM, pod kątem zarówno obecności gazów, jak i własności kolektorskich skał okołozłożowych, rozpoczęto dopiero po zdarzeniu wyrzutu gazów i skał w chodniku T-169a na poziomie 1200 m, mającego miejsce 6 września 2009 r. w ZG Rudna (Zawisza et al., 2010).

Celem podjętych badań było określenie zależności różnego typu parametrów geochemicznych z wykształceniem litologicznym badanych skał w nawiązaniu do badań petrofizycznych. Dla formacji miedzionośnych określenie tego typu prawidłowości oraz poznanie gazowych produktów generacji poszczególnych ich składników z różnych typów skał (m.in. piaskowca, dolomitu wapnistego, anhydrytu i soli kamiennej) pozwoli na przewidywanie kierunków ekshalacji gazowych, a w przyszłości może przyczynić się do utrzymania bezpieczeństwa w kopalniach (Kania i Janiga, 2018).

\section{Metodyka badań}

\section{Degazacja rdzeni skalnych}

Próbki rdzeni skalnych pobrane w kopalni miedzi (głównie $\mathrm{z}$ otworów), zostały umieszczone w szczelnych pojemnikach, tzw. kanistrach desorpcyjnych. Próbki dla oceny gazu desorbowanego, pobierano strzykawką wprost z pojemnika znad rdzenia i podawano do analizy chromatograficznej. Po wykonaniu analiz chromatograficznych z tych samych pojemników pobierano średnio po około $20 \mathrm{~g}$ próbki, którą rozdrabniano w zamkniętym cylindrze. Po zakończonym procesie degazacji pobierano gaz, nazywany gazem resztkowym, który nie wydzielił się samoistnie z próbki. Ilość gazu uzyskanego w wyniku rozdrobnienia skały wynosiła około $45 \mathrm{~cm}^{3}$ i po uwzględnieniu wielkości próbki i objętości pojemnika przeliczono każdy ze składników w stosunku do 1 kg próbki skalnej ( $\mu 1 / \mathrm{kg}$ skały) (Janiga i Kania, 2014).

Gaz desorbowany reprezentuje tę część gazu, która znajduje się w przestrzeni porowej i która może swobodnie migrować. Gaz resztkowy reprezentuje natomiast tę część gazu, która jest uwolniona ze skały po rozdrobnieniu próbki w przestrzeni zamkniętej (Diamond i Schatzel, 1998).

\section{Analiza sktadu molekularnego gazu}

Próbki gazowe poddano analizie chromatograficznej, określając zawartość następujących składników: $\mathrm{O}_{2}, \mathrm{~N}_{2}, \mathrm{CO}_{2}, \mathrm{CO}$, $\mathrm{C}_{1}, \mathrm{C}_{2}, \mathrm{C}_{3}, \mathrm{i}-\mathrm{C}_{4}, \mathrm{n}-\mathrm{C}_{4}$, neo- $\mathrm{C}_{5}, \mathrm{i}_{\mathrm{H}}, \mathrm{C}_{5}, \mathrm{n}-\mathrm{C}_{5}$ oraz sum węglowodorów $\mathrm{C}_{6}, \mathrm{C}_{7}, \mathrm{C}_{8}, \mathrm{C}_{9} \mathrm{iC}_{10}$. Do analizy $\mathrm{GC}$ zastosowano dwukanałowy, zaworowy chromatograf gazowy AGILENT 7890A oraz układ kolumn i detektorów (Kania i Janiga, 2011):

- detektor TCD i FID (FRONT) - kolumny kapilarne: HP-PLOT/Q, dług. $15 \mathrm{~m}$, śred. wewn. 0,53 mm; HP-PLOT/Q, dług. $30 \mathrm{~m}$, śred. wewn. 0,53 mm; HP-MOLESIEVE 5A, dług. $30 \mathrm{~m}$, śred. wewn. $0,53 \mathrm{~mm}$, - detektor FID (BACK) - kolumna kapilarna HP-PONA, dług. $50 \mathrm{~m}$, śred. wewn. 0,200 mm.

$\mathrm{W}$ trakcie analizy jako gazu nośnego użyto argonu z gradientem przepływu od $3 \mathrm{ml} / \mathrm{min}$ do $6 \mathrm{ml} / \mathrm{min}$. Zastosowano program temperaturowy kolumny od $35^{\circ} \mathrm{C}$ do $260^{\circ} \mathrm{C}$, temperaturę katalizatora niklowego $375^{\circ} \mathrm{C}$, temperaturę detektorów FID $300^{\circ} \mathrm{C}$ oraz temperaturę dozownika i detektora TCD $200^{\circ} \mathrm{C}$.

Do oznaczenia zawartości $\mathrm{H}_{2} \mathrm{i}$ He zastosowano chromatograf gazowy AGILENT 7890A oraz detektor cieplno-przewodnościowy (TCD - thermal conductivity detektor) i kolumnę pakowaną Molecular Sieve 5A Ultimetal 9FT × 1/8IN × 2,00 mm. Gazem nośnym podczas oceny zawartości $\mathrm{H}_{2}$ i He był argon o stałym przepływie $3 \mathrm{ml} / \mathrm{min}$. Zastosowano gradient temperaturowy kolumny od $30^{\circ} \mathrm{C}$ do $240^{\circ} \mathrm{C}$, temperaturę dozownika i detektora TCD $200^{\circ} \mathrm{C}$.

Natomiast do oznaczenia zawartości $\mathrm{H}_{2} \mathrm{~S}$ oraz innych związków siarki (merkaptan metylowy, merkaptan etylowy, siarczek dimetylowy, merkaptan i-propylowy, merkaptan n-propylowy, merkaptan i-butylowy, merkaptan n-butylowy) zastosowano chromatograf gazowy AGILENT 7890A oraz detektor płomieniowo-fotometryczny (FPD - flame photometric detektor) i kolumnę kapilarną DB-1 dług. 60 m, średn. 
wewn. $0,32 \mathrm{~mm}$, gdzie gazem nośnym był argon o stałym przepływie $3 \mathrm{ml} / \mathrm{min}$. Zastosowano gradient temperaturowy kolumny od $30^{\circ} \mathrm{C}$ do $240^{\circ} \mathrm{C}$, temperaturę dozownika $200^{\circ} \mathrm{C}$ oraz temperaturę detektora FPD $250^{\circ} \mathrm{C}$.

\section{Badania petrofizyczne}

Badanie i parametryzacja przestrzeni porowej została wykonana przy pomocy porozymetrii rtęciowej (porozymetr AutoPore IV 9500, Micromeritisc) przy ciśnieniach do 30 tys. psi, poprzez pomiar krzywych ciśnień kapilarnych. Natomiast pomiary gęstości wykonane zostały przy pomocy piknometru helowego AccuPyc 1340 firmy Micromeritisc. Gęstość szkieletową uzyskaną z piknometru helowego wykorzystuje się do korekty porowatości otwartej z pomiaru porozymetrycznego. Pomiary gęstości i porowatości zostały wykonane na tej samej próbce. Z kolei oznaczenie współczynnika przepuszczalności efektywnej wykonano przy użyciu azotu, jako gazu roboczego. Pomiar polega na doprowadzeniu do ustalonego, laminarnego przepływu gazu przez badaną próbkę i wyliczeniu współczynnika przepuszczalności przy pomocy równania Darcy'ego. Techniczne wykonanie pomiaru zależy od przyjętej geometrii pomiaru i rodzaju użytej próbki. Pomiary współczynnika przepuszczalności zostały wykonane dla tzw. geometrii liniowej, tj. gaz płynie przez próbkę o stałym przekroju i długości. Do tego typu badań stosuje się wycięte walce o średnicy 1 cala i długości 3-4 cm.

Tabela 1. Analiza statystyczna wyników badań składu gazu desorbowanego i resztkowego dla różnych typów skał

Table 1. Statistical analysis of the desorbed and residual gas composition research results for various types of rocks

\begin{tabular}{|c|c|c|c|c|c|c|c|c|}
\hline $\begin{array}{c}\text { Oznaczany } \\
\text { składnik gazu }\end{array}$ & $\sum$ ilość gazu & C1 & $\sum \mathbf{C H}$ & $\sum$ zw. S & $\mathrm{CO}_{2}$ & $\mathbf{N}_{2 \text { nadm. }}$ & $\mathbf{H}_{2}$ & He \\
\hline \multicolumn{9}{|c|}{ Dolomit wapnisty - gaz desorbowany } \\
\hline $\operatorname{Max}[\mu 1 / k g$ skały $]$ & 313815,2 & 381,8 & 569,0 & 0,1 & 11981,8 & 310844,0 & 2874,3 & 20,9 \\
\hline $\operatorname{Min}[\mu 1 / k g$ skały $]$ & 37,3 & 0,6 & 1,8 & 0,0 & 0,0 & 0,0 & 0,0 & 0,0 \\
\hline Średnia $[\mu 1 / k g$ skały $]$ & 16089,9 & 19,9 & 61,1 & 0,0 & 525,6 & 15195,4 & 300,3 & 0,2 \\
\hline Mediana $[\mu 1 / \mathrm{kg}$ skały $]$ & 627,0 & 9,2 & 27,7 & 0,0 & 174,2 & 0,0 & 113,0 & 0,0 \\
\hline Rozstęp [ $\mu 1 / k g$ skały] & 313777,9 & 381,2 & 567,2 & 0,1 & 11981,8 & 310844,0 & 2874,3 & 20,9 \\
\hline Ilość próbek & 127 & 127 & 127 & 127 & 127 & 127 & 127 & 127 \\
\hline \multicolumn{9}{|c|}{ Dolomit wapnisty - gaz resztkowy } \\
\hline $\operatorname{Max}[\mu 1 / k g$ skały $]$ & 126483,2 & 4418,7 & 10509,9 & 0,5 & 22060,4 & 106474,0 & 1377,2 & 141,7 \\
\hline $\operatorname{Min}[\mu 1 / k g$ skały] & 490,3 & 41,7 & 82,1 & 0,0 & 0,0 & 0,0 & 0,0 & 0,0 \\
\hline Średnia [ $\mu 1 / \mathrm{kg}$ skały] & 21659,7 & 1299,2 & 2568,7 & 0,0 & 8555,2 & 10303,3 & 224,5 & 1,1 \\
\hline Mediana $[\mu 1 / \mathrm{kg}$ skały $]$ & 16013,7 & 1167,9 & 2212,8 & 0,0 & 7531,8 & 1216,9 & 166,6 & 0,0 \\
\hline Rozstęp [ $\mu 1 / k g$ skały] & 125992,9 & 4377,0 & 10427,8 & 0,5 & 22060,4 & 106474,0 & 1377,2 & 141,7 \\
\hline Ilość próbek & 127 & 127 & 127 & 127 & 127 & 127 & 127 & 127 \\
\hline \multicolumn{9}{|c|}{ Anhydryt - gaz desorbowany } \\
\hline $\operatorname{Max}[\mu 1 / k g$ skały] & 84128,8 & 2656,5 & 11535,6 & 0,1 & 4651,1 & 67918,0 & 1243,4 & 0,0 \\
\hline Min $[\mu 1 / k g$ skały] & 2,4 & 0,0 & 0,0 & 0,0 & 0,8 & 0,0 & 0,0 & 0,0 \\
\hline Średnia $[\mu \mathrm{l} / \mathrm{kg}$ skały] & 2060,8 & 58,0 & 163,5 & 0,0 & 500,0 & 1288,2 & 102,7 & 0,0 \\
\hline Mediana $[\mu 1 / \mathrm{kg}$ skały $]$ & 399,8 & 10,1 & 26,2 & 0,0 & 197,9 & 0,0 & 44,8 & 0,0 \\
\hline Rozstęp [ $\mu 1 / \mathrm{kg}$ skały] & 84126,4 & 2656,5 & 11535,6 & 0,1 & 4650,3 & 67918,0 & 1243,4 & 0,0 \\
\hline Ilość próbek & 124 & 124 & 124 & 124 & 124 & 124 & 124 & 124 \\
\hline \multicolumn{9}{|c|}{ Anhydryt - gaz resztkowy } \\
\hline $\operatorname{Max}[\mu 1 / k g$ skały] & 52370,7 & 5747,1 & 17161,8 & 903,4 & 20971,8 & 33892,9 & 1312,9 & 0,0 \\
\hline Min [ $\mu 1 /$ kg skały] & 48,9 & 23,2 & 34,0 & 0,0 & 0,0 & 0,0 & 0,0 & 0,0 \\
\hline Średnia $[\mu 1 / k g$ skały] & 4615,4 & 547,1 & 1349,8 & 7,6 & 1513,2 & 1643,3 & 96,9 & 0,0 \\
\hline Mediana $[\mu 1 / \mathrm{kg}$ skały] & 1197,2 & 345,2 & 636,2 & 0,0 & 0,0 & 0,0 & 73,2 & 0,0 \\
\hline Rozstęp [ $\mu 1 /$ kg skały] & 52321,8 & 5723,9 & 17127,8 & 903,4 & 20971,8 & 33892,9 & 1312,9 & 0,0 \\
\hline Ilość próbek & 124 & 124 & 124 & 124 & 124 & 124 & 124 & 124 \\
\hline
\end{tabular}


cd. Tabela $1 /$ ect. Table 1

\begin{tabular}{|c|c|c|c|c|c|c|c|c|}
\hline $\begin{array}{c}\text { Oznaczany } \\
\text { składnik gazu }\end{array}$ & $\sum$ ilość gazu & C1 & $\sum \mathbf{C H}$ & $\sum$ zw. S & $\mathrm{CO}_{2}$ & $\mathbf{N}_{2 \text { nadm. }}$ & $\mathbf{H}_{2}$ & $\mathrm{He}$ \\
\hline \multicolumn{9}{|c|}{ Sól kamienna - gaz desorbowany } \\
\hline $\operatorname{Max}[\mu 1 / k g$ skały $]$ & 1567031,2 & 3493,3 & 6125,1 & 12,2 & 5281,1 & 1565945,7 & 56856,4 & 107,5 \\
\hline $\operatorname{Min}[\mu 1 / k g$ skały $]$ & 12,1 & 0,9 & 1,0 & 0,0 & 0,0 & 0,0 & 0,0 & 0,0 \\
\hline Średnia $[\mu 1 / k g$ skały] & 62597,2 & 62,0 & 200,3 & 0,2 & 379,2 & 61062,9 & 949,5 & 1,0 \\
\hline Mediana $[\mu 1 / \mathrm{kg}$ skały] & 470,0 & 7,9 & 26,9 & 0,0 & 149,0 & 0,0 & 0,0 & 0,0 \\
\hline Rozstęp [ $\mu 1 / k g$ skały] & 1567019,1 & 3492,4 & 6124,1 & 12,2 & 5281,1 & 1565945,7 & 56856,4 & 107,5 \\
\hline Ilość próbek & 108 & 108 & 108 & 108 & 108 & 108 & 108 & 108 \\
\hline \multicolumn{9}{|c|}{ Sól kamienna - gaz resztkowy } \\
\hline $\operatorname{Max}[\mu 1 / k g$ skały $]$ & 274470,3 & 515,5 & 4564,5 & 6,0 & 7098,8 & 274205,1 & 913,1 & 184,4 \\
\hline $\operatorname{Min}[\mu 1 / k g$ skały $]$ & 7,8 & 5,8 & 5,9 & 0,0 & 0,0 & 0,0 & 0,0 & 0,0 \\
\hline Średnia $[\mu 1 / k g$ skały] & 13539,0 & 51,2 & 253,5 & 0,3 & 921,9 & 12293,1 & 60,8 & 9,5 \\
\hline Mediana $[\mu 1 / \mathrm{kg}$ skały] & 3331,4 & 24,8 & 58,8 & 0,0 & 430,2 & 1827,0 & 0,0 & 0,0 \\
\hline Rozstęp [ $\mu 1 / k g$ skały] & 274462,5 & 509,7 & 4558,6 & 6,0 & 7098,8 & 274205,1 & 913,1 & 184,4 \\
\hline Ilość próbek & 108 & 108 & 108 & 108 & 108 & 108 & 108 & 108 \\
\hline \multicolumn{9}{|c|}{ Piaskowiec - gaz desorbowany } \\
\hline $\operatorname{Max}[\mu 1 / k g$ skały] & 59759,2 & 218,7 & 234,2 & 0,8 & 2068,9 & 58470,1 & 1265,4 & 0,0 \\
\hline $\operatorname{Min}[\mu 1 / k g$ skały] & 10,3 & 1,2 & 1,2 & 0,0 & 0,0 & 0,0 & 0,0 & 0,0 \\
\hline Średnia $[\mu 1 / k g$ skały] & 7033,4 & 11,4 & 21,1 & 0,0 & 260,9 & 6685,1 & 59,7 & 0,0 \\
\hline Mediana $[\mu 1 / k g$ skały] & 489,2 & 4,8 & 9,9 & 0,0 & 40,2 & 0,0 & 0,0 & 0,0 \\
\hline Rozstęp [ $\mu 1 /$ kg skały] & 59748,9 & 217,5 & 233,0 & 0,8 & 2068,9 & 58470,1 & 1265,4 & 0,0 \\
\hline Ilość próbek & 47 & 47 & 47 & 47 & 47 & 47 & 47 & 47 \\
\hline \multicolumn{9}{|c|}{ Piaskowiec - gaz resztkowy } \\
\hline $\operatorname{Max}[\mu 1 / k g$ skały $]$ & 789909,4 & 1324,4 & 3749,0 & 0,6 & 17731,1 & 783276,1 & 11044,2 & 133,6 \\
\hline Min $[\mu 1 / k g$ skały] & 2317,7 & 18,4 & 24,5 & 0,0 & 1598,0 & 0,0 & 0,0 & 0,0 \\
\hline Średnia $[\mu 1 / k g$ skały] & 160828,5 & 184,9 & 407,8 & 0,0 & 5443,7 & 153568,2 & 1380,7 & 2,8 \\
\hline Mediana $[\mu 1 / \mathrm{kg}$ skały] & 112363,0 & 127,1 & 163,6 & 0,0 & 4786,3 & 101368,1 & 405,6 & 0,0 \\
\hline Rozstęp [ $\mu 1 / k g$ skały] & 787591,7 & 1306,0 & 3724,5 & 0,6 & 16133,1 & 783276,1 & 11044,2 & 133,6 \\
\hline Ilość próbek & 47 & 47 & 47 & 47 & 47 & 47 & 47 & 47 \\
\hline
\end{tabular}

\section{Część doświadczalna}

\section{Charakterystyka próbek $i$ wyniki badań}

Próbki skał, pochodzące $\mathrm{z}$ utworów miedzionośnych z rejonu Sieroszowic o zróżnicowanym wykształceniu litolofacjalnym, reprezentujące m.in. anhydryt, dolomit wapnisty, sól kamienną oraz piaskowiec poddano szczegółowym badaniom petrofizycznym i chromatograficznym. Dla tych samych próbek dokonano oceny składu molekularnego i ilości wydzielonych gazów (zarówno desorbowanych i resztkowych) dla licznej grupy próbek, reprezentujących różne typy skał (o różnych właściwościach petrofizycznych).

W celu lepszego usystematyzowania informacji o miejscach kumulacji gazowych, a tym samym do skorelowania różnych parametrów między sobą, z bardzo licznej grupy próbek wytypowano 47 próbek piaskowca, 108 próbek soli kamiennej, 127 próbek dolomitu wapnistego i 124 próbki anhydrytu, dla których przeprowadzono analizę statystyczną wyników badań wydzielonych gazów (tab. 1) i wybranych parametrów petrofizycznych (tab. 2).

\section{Korelacja pomiędzy ilościa gazu a wyksztatceniem litofacjalnym na tle właściwości petrofizycznych}

Poszczególne serie skalne występujące w otoczeniu złóż rud miedzi, tj. piaskowce czerwonego spągowca (P1) obecne w spągu złoża oraz występujące w części stropowej kolejno: seria skał węglanowych wapienia cechsztyńskiego (Ca1), anhydryty dolny i górny (A1d i A1g), a także najstarsza sól kamienna (Na1), mogą stanowić lokalnie odrębne strefy akumulacji gazów (Zawisza et al., 2010). Stąd też w niniejszej pracy 


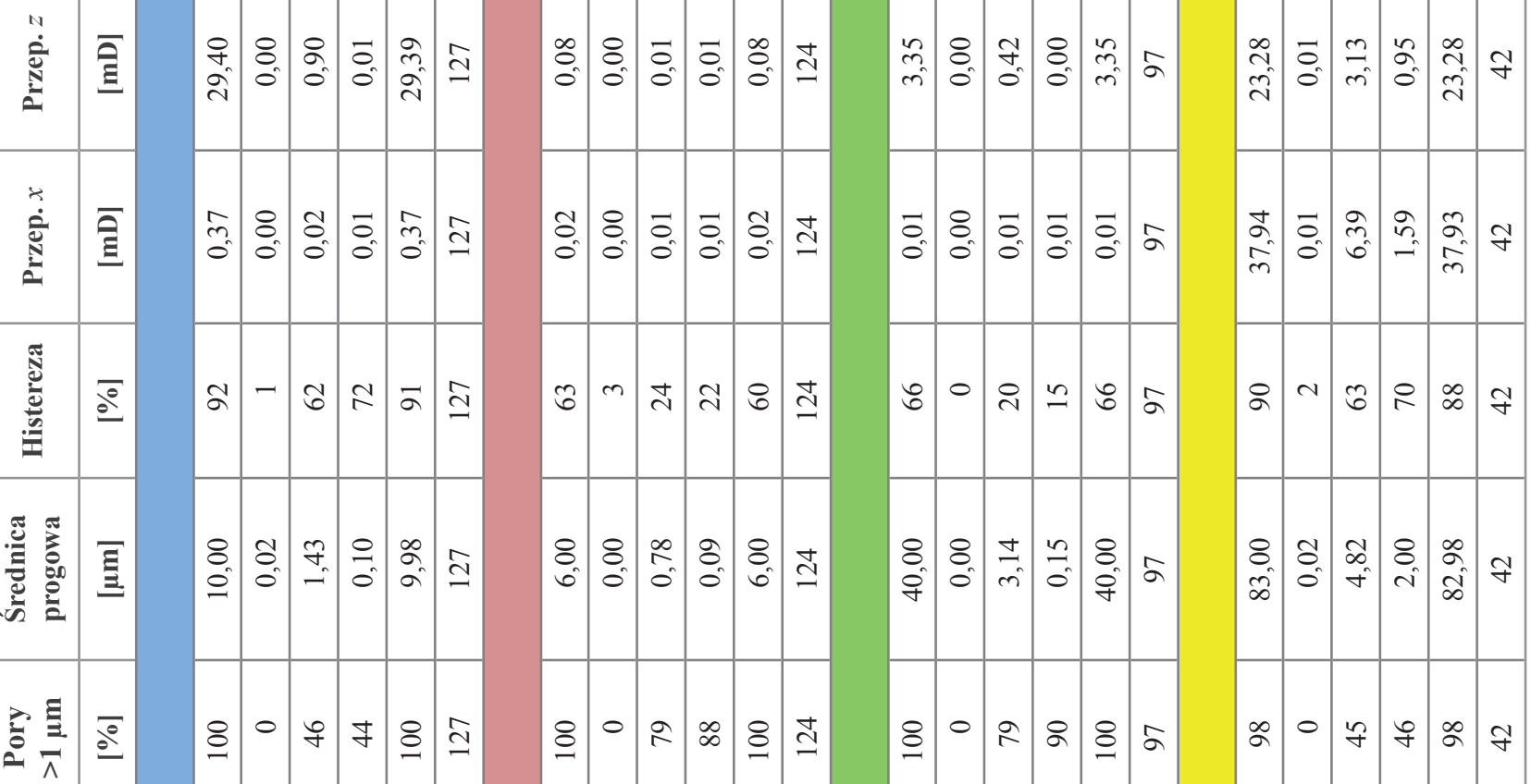

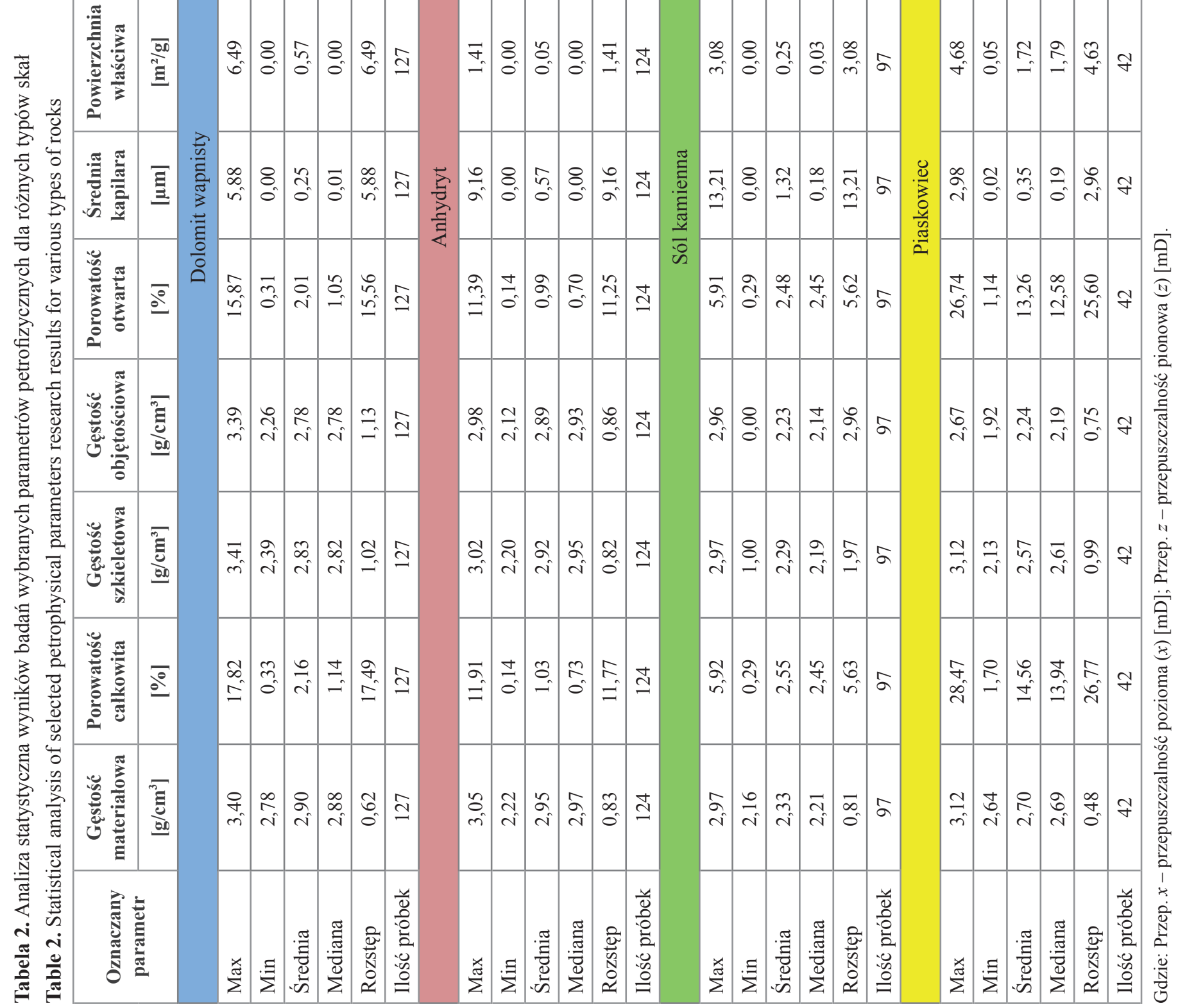


dokonano szczegółowej oceny ilościowo-jakościowej ich warunków gazowych.

Analizując liczne wyniki badań chromatograficznych (tab. 1, rys. 1) polegające na oznaczeniu składu ilościowojakościowego gazów zawartych w rdzeniach wiertniczych łatwo zauważyć fakt, iż zdecydowanie najwyższa średnia ilość gazu resztkowego uzyskana została z piaskowców i wynosiła $160829 \mu \mathrm{l} / \mathrm{kg}$ skały. Nieco mniejsze ilości gazu resztkowego wydzieliły się z kolei z próbek dolomitu wapnistego, gdzie ich średnia wartość wyniosła $21660 \mu \mathrm{l} / \mathrm{kg}$ skały. Jeszcze mniejsze ilości gazu resztkowego zanotowano dla soli kamiennej - Nal (13 $539 \mu \mathrm{l} / \mathrm{kg}$ skały), a najniższe dla próbek anhydrytowych (4615 $\mu 1 / \mathrm{kg}$ skały). Średnie ilości wydzielonego gazu resztkowego doskonale korelują się z właściwościami petrofizycznymi, takimi jak: średnie wartości porowatości całkowitej (rys. 2) i otwartej (rys. 5), powierzchnia właściwa (rys. 7) oraz przepuszczalność pionowa (rys. 9). Do sporządzenia wykresów i diagramów korelacyjnych wykorzystano wyniki przepuszczalności pionowej $(z)$, a nie poziomej $(x)$ ze względu na zdecydowanie większą liczbę pozytywnych pomiarów petrofizycznych.

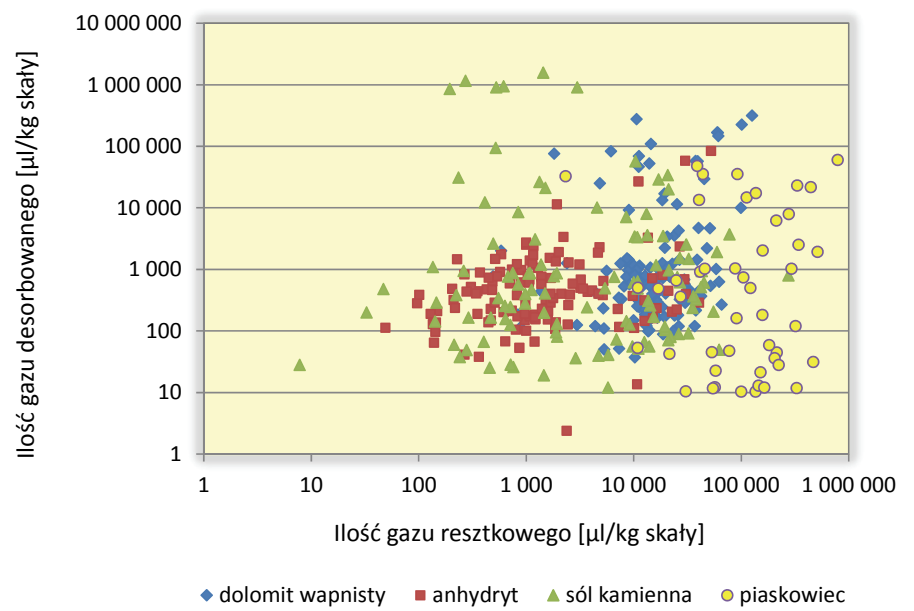

Rys. 1. Zależność sumarycznej ilości gazu desorbowanego od resztkowego dla różnych typów skał

Fig. 1. Dependence of the total amount of desorbed gas from residual gas for various rock types

Z kolei próbki soli kamiennej charakteryzują się anomalnie wysokimi ilościami gazu desorbowanego (rys. 2), co wiąże się z dużą zawartością azotu nadmiarowego wydzielonego $z$ otwartej przestrzeni porowej rdzenia (tab. 1). Azot, a tym samym duże ilości gazu desorbowanego w pokładach soli kamiennej można tłumaczyć selektywną adsorpcją gazu podczas migracji na duże odległości. Migracja gazu prawdopodobnie nastąpiła przez pęknięcia i szczeliny z utworów karbonu, czerwonego spągowca i wapienia cechsztyńskiego (Kotarba et al., 2006). Azot może mieć również biogenne pochodzenie (Poszytek et al., 2018).
Próbki pochodzące z serii piaskowcowej (zarówno czerwonego piaskowca, jak i białego) charakteryzują się najwyższą średnią porowatością całkowitą (rys. 2 i 3), o wartości 14,6\% (i bardzo dużym rozrzutem wyników w zakresie od 1,7\% do $28,5 \%$ ). W tychże porach zostały również skumulowane i zamknięte największe ilości gazu, zwanym resztkowym (w zakresie od 2318 do $789909 \mu 1 /$ kg skały).

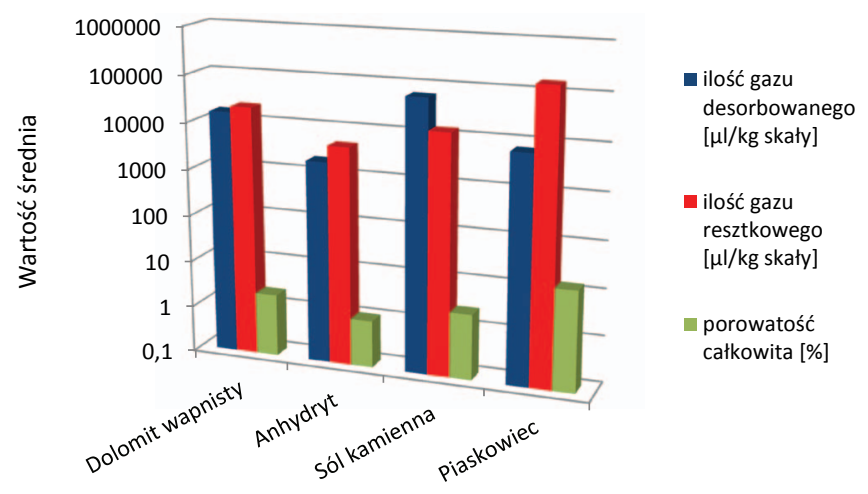

Rys. 2. Diagram przedstawiający wartości średnich ilości gazu (desorbowanego i resztkowego) oraz porowatości całkowitej dla rdzeni o różnym wykształceniu litologicznym

Fig. 2. Diagram presenting the average values of the amount of gas (desorbed and residual) and the total porosity for cores of different lithology

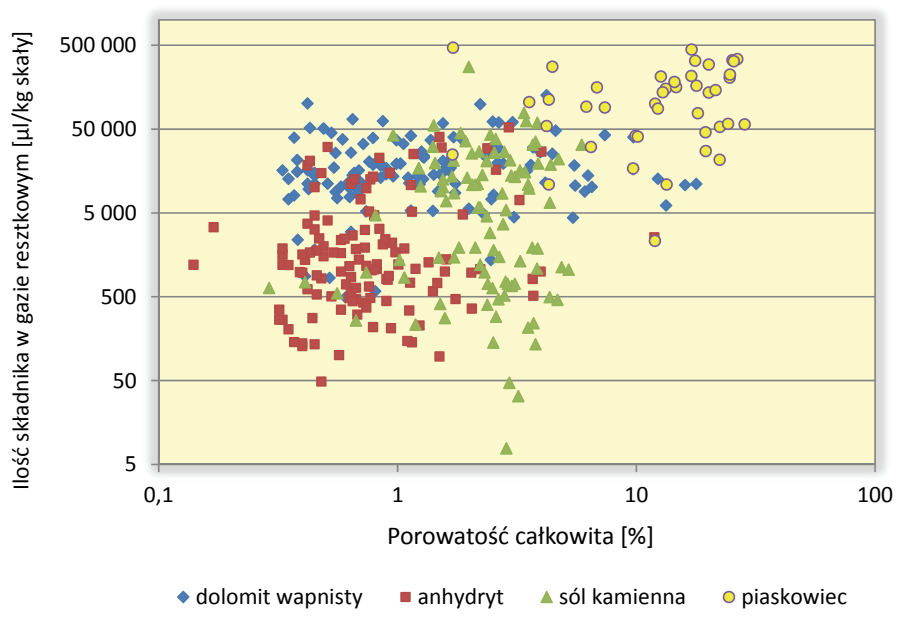

Rys. 3. Ilość gazu resztkowego w funkcji porowatości całkowitej dla próbek rdzeniowych o różnym wykształceniu litologicznym

Fig. 3. The residual gas amount as a function of the total porosity for core samples of different lithology

Według licznych doniesień w utworach piaskowcowych czerwonego spągowca, posiadających znaczne rozprzestrzenienie i występujących na przeważającej powierzchni obszaru całej monokliny przedsudeckiej, następuje przepływ lateralny gazów od NE w kierunku SW, to jest w kierunku LGOM. Wysoka porowatość i stosunkowo niska przepuszczalność piaskowców, umożliwiają tworzenie się lokalnych ,zamkniętych” pułapek gazu, szczególnie w strefach dyslokacji tektonicznych 
i towarzyszących im spękań i szczelin (Zawisza et al., 2010). Ponadto słabe warunki zbiornikowe piaskowców mogą sprzyjać powstawaniu niekonwencjonalnych nagromadzeń gazu typu tight gas (Kiersnowski et al., 2010).

Dodatkowo brak serii łupków miedzionośnych lub znaczna redukcja miąższości (nawet poniżej 0,1 m) jest cechą charakterystyczną elewacji, co ułatwia migrację gazu ku górze, w utwory węglanowe cechsztynu. Piaskowiec budujący elewacje jest silnie porowaty, przepuszczalny, co dodatkowo sprzyja zjawisku migracji gazu w tych strefach (Zawisza et al., 2010).

Z kolei cechsztyńskie skały węglanowe cyklotemu Werra, określane w literaturze geologicznej, jako wapień cechsztyński (Ca1), charakteryzują się znacznym zróżnicowaniem dotyczącym: miąższości, wykształcenia litologicznego i facjalnego oraz intensywności procesów diagenetycznych (Zawisza et al., 2010). Przykładowo w obrębie cechsztyńskich skał węglanowych Ca1 w rejonie ZG Rudna wyróżniono kilka typów dolomitów o różnych właściwościach petrofizycznych, zróżnicowanych zarówno pod względem porowatości sięgającej nawet 15\%, jak i przepuszczalności (Poszytek i Suchan, 2016; Poszytek et al., 2018). Obecność gazu zamkniętego w porach dolomitów jest zjawiskiem dość powszechnym, jednak to obecność wysokociśnieniowych pułapek gazowych w obrębie lokalnie bardziej porowatych, mikroszczelinowatych i przepuszczalnych dolomitów stanowi zasadnicze zagrożenie (Suchan et al., 2013). Podobnie w przypadku opisywanych w literaturze próbek rdzeniowych $\mathrm{z}$ rejonu Rudnej, tak i dla badanych w ramach niniejszego opracowania próbek dolomitów wapnistych z rejonu Sieroszowic można zauważyć duże zróżnicowanie wyników. Dotyczy to zarówno oznaczeń ilościowo-jakościowych gazów, jak i właściwości petrofizycznych skał (przykładowo porowatość całkowita dla próbek dolomitu wapnistego wahała się w zakresie od $0,3 \%$ do $17,8 \%$ ).

Należy brać również pod uwagę fakt, iż warunki strukturalne monokliny przedsudeckiej powodują, że prawdopodobna jest możliwość migracji gazu z dolomitu głównego do wapienia cechsztyńskiego (Kotarba et al., 2017).

Porowatość otwarta, jako parametr charakteryzujący przepuszczalność badanych skał (Such, 1997; Sowiżdżał et al., 2017) w analogiczny sposób, jak w przypadku porowatości całkowitej, koreluje z ilością wydzielonego gazu resztkowego. Dla grupy piaskowców średnia wartość porowatości otwartej wyniosła 13,3\% (oraz rozrzutem wyników w zakresie od $1,1 \%$ do 26,7\%), dla dolomitów wapnistych 2,0\% (w zakresie od $0,3 \%$ do $15,9 \%$ ), dla soli kamiennej 2,5\% (z zdecydowanie mniejszym rozrzutem wyników od $0,3 \%$ do $5,9 \%$ ) oraz dla anhydrytów $1,0 \%$ (w zakresie od $0,1 \%$ do $11,4 \%$ ) - rys. 4 i 5 .

Powierzchnia właściwa, jako sumaryczna powierzchnia porów przypadająca na jednostkę masy badanej skały, jest miarą wielkości oporu stawianego przez ośrodek

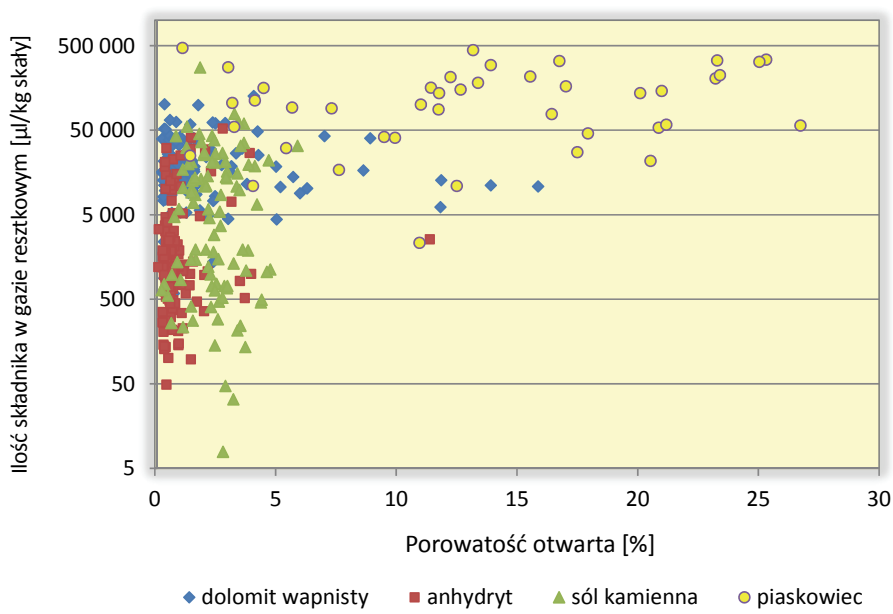

Rys. 4. Ilość gazu resztkowego w funkcji porowatości otwartej dla próbek rdzeniowych o różnym wykształceniu litologicznym

Fig. 4. The residual gas amount as a function of the open porosity for core samples of different lithology

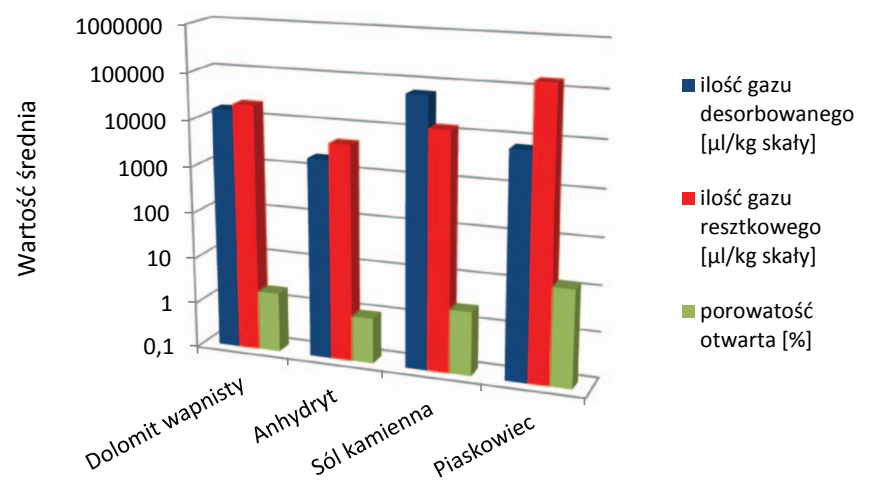

Rys. 5. Diagram przedstawiający wartości średnich ilości gazu (desorbowanego i resztkowego) oraz porowatości otwartej dla rdzeni o różnym wykształceniu litologicznym

Fig. 5. Diagram presenting the average values of the amount of gas (desorbed and residual) and the open porosity for cores of different lithology

porowaty przepływającemu płynowi. Średnia wartość powierzchni właściwej dla próbek reprezentujących piaskowiec wyniosła $-1,7 \mathrm{~m}^{2} / \mathrm{g}$, dolomit wapnisty $-0,6 \mathrm{~m}^{2} / \mathrm{g}$, sól kamienną $-0,3 \mathrm{~m}^{2} / \mathrm{g}$ oraz anhydryt $0,1 \mathrm{~m}^{2} / \mathrm{g}$. Parametr ten jest skorelowany z wydzielonymi ilościami gazu resztkowego dla poszczególnych litologii (rys. 6 i 7).

Próbki pochodzące z serii piaskowcowej charakteryzują się najwyższą średnią przepuszczalnością pionową o wartości 3,1 mD (i bardzo dużym rozrzutem wyników w zakresie od $0,01 \mathrm{mD}$ do $23,3 \mathrm{mD}$ ). Stosunkowo wysokie wartości przepuszczalności pionowej stwierdzono także dla próbek dolomitu wapnistego, gdzie średnia wyniosła 0,9 mD, w szerokim zakresie pomiarów od 0 do 29,4 mD.

Na podstawie dostępnych wyników badań przepuszczalności (tab. 2) dla próbek anhydrytowych można stwierdzić, że w analizowanym obszarze, nie ma warunków do złożowej 


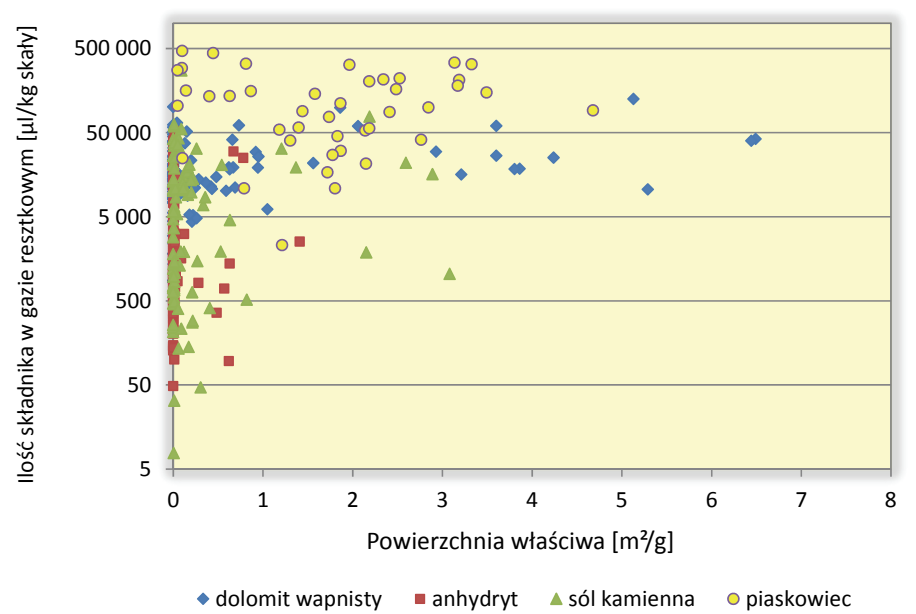

Rys. 6. Ilość gazu resztkowego w funkcji powierzchni właściwej dla próbek rdzeniowych o różnym wykształceniu litologicznym

Fig. 6. The residual gas amount as a function of the specific surface area for core samples of different lithology

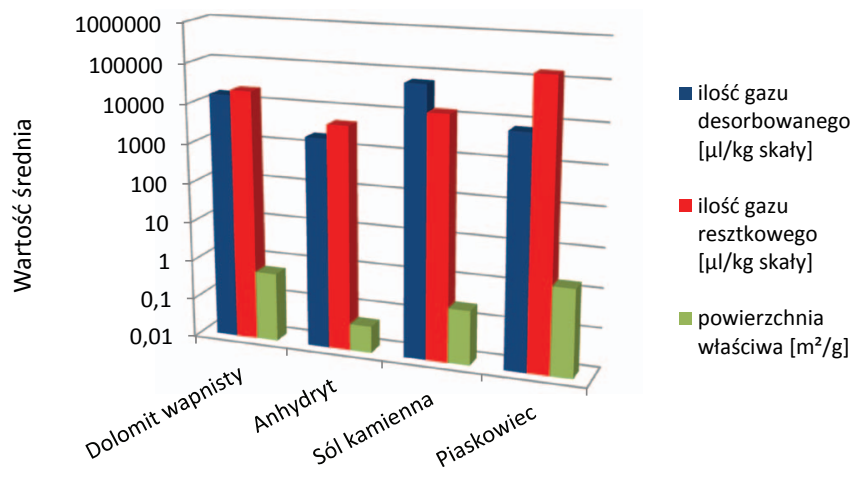

Rys. 7. Diagram przedstawiający wartości średnich ilości gazu (desorbowanego i resztkowego) oraz powierzchni właściwej dla rdzeni o różnym wykształceniu litologicznym

Fig. 7. Diagram presenting the average values of the amount of gas (desorbed and residual) and the specific surface area for cores of different lithology

koncentracji gazu ze względu na ich słabe właściwości kolektorskie skał (tj. bardzo niską przepuszczalność - rys. 9). Pojawiają się jednak warunki do wystąpienia lokalnych pułapek gazu w strefach o podwyższonej porowatości (nawet do $11,9 \%$ - tab. 2). W anhydrytach mogą zatem występować zamknięte ,pułapki gazowe” o stosunkowo niewielkich rozmiarach, zawierające znaczne zawartości węglowodorów oraz ilości siarkowodoru (tab. 1).

Generalnie próbki soli kamiennej, charakteryzowane jako mało przepuszczalne dla gazów (Zawisza et al., 2010), wykazują średnią porowatość całkowitą rzędu 2,6\% (z stosunkowo dużym rozrzutem wyników od $0,3 \%$ do aż $5,9 \%$ ) oraz wartościami przepuszczalności pionowej sięgającymi maksymalnie $3,4 \mathrm{mD}$. Przeprowadzona analiza wzajemnego usytuowania spągu cechsztynu oraz pokładu soli zalegającego pomiędzy poziomem eksploatacji, a dolomitem głównym wskazuje,

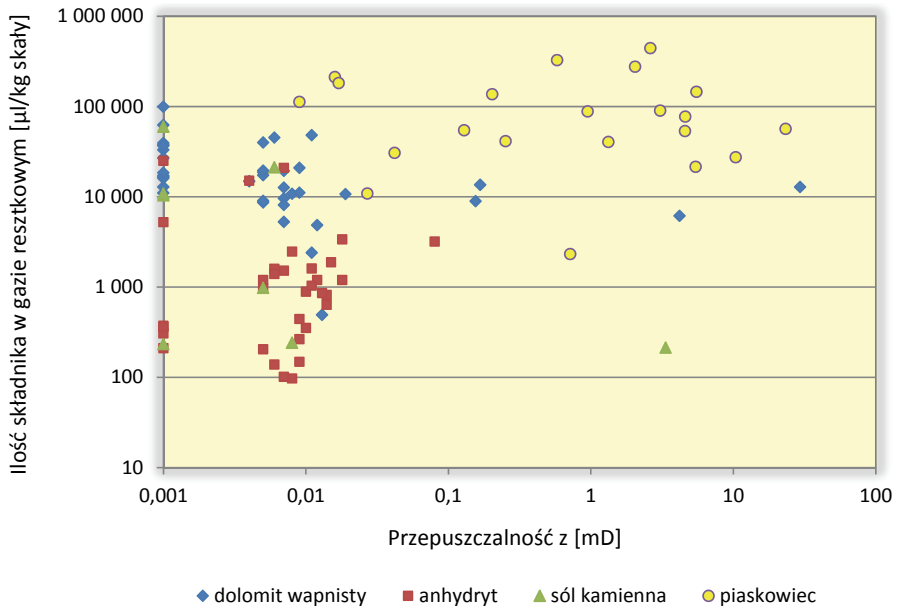

Rys. 8. Ilość gazu resztkowego w funkcji przepuszczalności pionowej $(z)$ dla próbek rdzeniowych o różnym wykształceniu litologicznym

Fig. 8. The residual gas amount as a function of the vertical permeability $(z)$ for core samples of different lithology

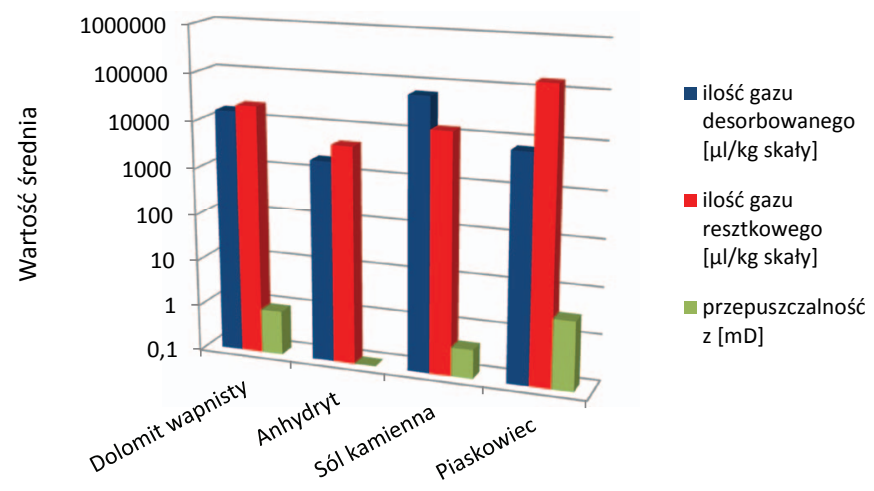

Rys. 9. Diagram przedstawiający wartości średnich ilości gazu (desorbowanego i resztkowego) oraz przepuszczalności pionowej (z) dla rdzeni o różnym wykształceniu litologicznym

Fig. 9. Diagram presenting the average values of the amount of gas (desorbed and residual) and the vertical permeability $(z)$ for cores of different lithology

że ukształtowanie powierzchni spągowej pokładu soli jest nieregularne, a jej odległość od poziomu eksploatacji jest zmienna (Kondratowicz, 1998). Odległość ta wynosi od minimum około $20 \mathrm{~m}$ do maksimum około $105 \mathrm{~m}$. Nieregularne ukształtowanie spągu nieprzepuszczalnego pokładu soli, może sprzyjać tworzeniu się pułapek dla gazu, w których mogą występować węglowodory typu syngenetycznego, stwarzające zagrożenie dla wyrobisk górniczych (Zawisza et al., 2010).

\section{Dyskusja i wnioski}

Na podstawie wieloletnich badań dotyczących występowania objawów gazu i ropy w rejonie LGOM, zaobserwowano pewne prawidłowości, które posiadają analogię w stosunku 
do prawidłowości stwierdzonych dla całej monokliny przedsudeckiej. Dotyczy to zarówno zmienności w przestrzennym rozkładzie składu chemicznego gazu, w tym procentowego udziału węglowodorów, jak również powiązania zjawisk występowania gazu z pionowym profilem geologiczno-strukturalnym złoża, własnościami kolektorskimi skał budujących poszczególne poziomy litostratygraficzne, a także ze zjawiskami genetyczno-migracyjnymi (Zawisza et al., 2010).

W artykule przedstawiono korelację różnego typu parametrów geochemicznych z wykształceniem litologicznym badanych skał, pochodzących przede wszystkim z utworów miedzionośnych, w nawiązaniu do ich właściwości petrofizycznych. Badania przeprowadzono zarówno na próbkach gazu desorbowanego oraz na próbkach gazu resztkowego i na tej podstawie zostały określone pewne prawidłowości zmian jakościowo-ilościowych:

1. Ilość i skład molekularny gazów desorbowanych oraz gazów wydzielonych w trakcie degazacji rdzeni skalnych jest mocno skorelowany z wykształceniem litofacjanym badanych rdzeni (Kania i Janiga, 2018).

2. Badane próbki soli kamiennej o anomalnie wysokich ilościach gazu desorbowanego, wiążą się z dużą zawartością azotu nadmiarowego wydzielonego z otwartej przestrzeni porowej rdzenia. Azot, a tym samym duże ilości gazu desorbowanego w pokładach soli kamiennej można tłumaczyć selektywną adsorpcją gazu podczas migracji na duże odległości (prawdopodobnie z warstw karbońskich oraz ze złóż czerwonego spągowca (Kotarba et al., 2006) i wapienia cechsztyńskiego), chociaż azot może również mieć biogenne pochodzenie (Poszytek et al., 2018).

3. Zdecydowanie najwyższa ilość gazu resztkowego uzyskana została z serii piaskowców. Nieco mniejsze ilości gazu wydzieliły się z kolei z próbek dolomitu wapnistego, jeszcze mniejsze zanotowano dla soli kamiennej, a najniższe dla próbek anhydrytowych. Średnie ilości wydzielonego gazu resztkowego doskonale korelują się z właściwościami petrofizycznymi, takimi jak: średnie wartości porowatości całkowitej i otwartej, powierzchnia właściwa oraz przepuszczalność.

4. Piaskowiec jest silnie porowaty i przepuszczalny, co sprzyja zjawisku kumulacji oraz migracji gazu w tych strefach (najwyższa średnia ilość gazu resztkowego spośród badanych litologii).

5. Na podstawie przeprowadzonej analizy dla badanych w ramach niniejszego opracowania próbek dolomitów wapnistych z rejonu Sieroszowic można zauważyć duże zróżnicowanie wyników. Dotyczy to zarówno oznaczeń ilościowo-jakościowych gazów, jak i właściwości petrofizycznych skał (przykładowo porowatość całkowita dla próbek dolomitu wapnistego wahała się w zakresie od $0,3 \%$ do maksymalnie 17,8\% (gdzie mogą być kumulowane duże ilości gazu, co stanowi zasadnicze zagrożenie).

6. Dostępne wyniki badań przepuszczalności dla próbek anhydrytowych sugerują, że w analizowanym obszarze, nie ma warunków do złożowej koncentracji gazu ze względu na słabe właściwości kolektorskie skał (tj. bardzo niską przepuszczalność). Pojawiają się jednak warunki do wystąpienia lokalnych pułapek gazu w strefach o podwyższonej porowatości (nawet do 11,9\%). W anhydrytach mogą zatem występować zamknięte ,pułapki gazowe” o stosunkowo niewielkich rozmiarach, zawierające znaczne zawartości węglowodorów oraz ilości siarkowodoru.

7. Badane próbki soli kamiennej wykazują średnią porowatość całkowitą rzędu 2,6\% (z stosunkowo dużym rozrzutem wyników od $0,3 \%$ do aż 5,9\%) oraz wartościami przepuszczalności pionowej sięgającymi maksymalnie 3,4 mD. Nieregularne ukształtowanie spągu mało przepuszczalnego pokładu soli może zatem sprzyjać tworzeniu się pułapek dla gazu o wysokich zawartościach azotu nadmiarowego z domieszką węglowodorów, stanowiąc zagrożenie dla wyrobisk górniczych.

8. Wykonane prace potwierdzają celowość prowadzenia badań składu gazu desorbowanego i resztkowego, w celu przewidywania kierunków ekshalacji gazowych, co może przyczynić się do utrzymania bezpieczeństwa w kopalniach.

Artykuł powstał na podstawie pracy statutowej pt.: Ocena jakościowo-ilościowa gazów pochodzacych z degazacji rdzeni skalnych na tle wtaściwości petrofizycznych - praca INiG - PIB na zlecenie MNiSW; nr zlecenia: 47/SG/2018, nr archiwalny: DK-4100-47/2018.

\section{Literatura}

Diamond W.P., Schatzel S.J., 1998. Measuring the gas content of coal: a review. International Journal of Coal Geology, 35: 311-331.

Downorowicz S., 2007. Występowanie gazu ziemnego i ropy naftowej. Monografia KGHM Polska Miedź S.A.

Janiga M., Kania M., 2014. Degazacja próbek skał - ocena ilościowa i jakościowa gazu resztkowego. Nafta-Gaz, 1: 8-13.

Kania M., Janiga M., 2011. Elementy walidacji metody analitycznej oznaczania w mieszaninie gazowej związków węglowodorowych oraz $\mathrm{N}_{2}, \mathrm{O}_{2}, \mathrm{CO}$ i $\mathrm{CO}_{2}$ za pomocą dwukanałowego, zaworowego chromatografu gazowego AGILENT 7890A. Nafta-Gaz, 11: $812-824$

Kania M., Janiga M., 2018. Wpływ wykształcenia litofacjalnego na ilośći skład molekularny gazu desorbowanego i resztkowego. Nafta-Gaz, 12: 884-893. DOI: 10.18668/NG.2018.12.02.

Kiersnowski H., Buniak A., Kuberska M., Srokowska-Okońska A., 2010. Występowanie gazu ziemnego zamkniętego w piaskowcach czerwonego spagowca Polski. Przegląd Geologiczny, 58(4): 335-346.

Kłapciński J., Peryt T.M., 2007. Budowa geologiczna monokliny przedsudeckiej. Monografia KGHM Polska Miedź S.A.

Kondratowicz G., 1998. Prognoza zagrożenia gazowego złoża rud miedzi zalegającego poniżej poziomu $1200 \mathrm{~m}$. Wrocław: Cuprum, 9: $97-118$. 
Kotarba M.J., Bilkiewicz E., Manecki M., Pawlik W., Ciesielczyk A., Selerowicz T., 2017. Pochodzenie i zagrożenia siarkowodorem i wysokociśnieniowym gazem ziemnym w złożu kopalń rud miedzi Polkowice-Sieroszowice i Rudna - wstępne badania izotopowe i mineralogiczne. Biuletyn Państwowego Instytutu Geologicznego, 469: 9-34. DOI: 10.5604/01.3001.0010.0068.

Kotarba M.J., Peryt T.M., Kosakowski P., Więcław D., 2006. Organic geochemistry, depositional history and hydrocarbon generation modelling of the Upper Permian Kupferschiefer and Zechstein Limestone strata in south-west Poland. Marine and Petroleum Geology, 23: 371-386.

Poszytek A., Dudek L., Rożek R., 2018. Presence of natural gas in basinal facies of the Zechstein Limestone in a Copper Mine in SW Poland, Journal of Petroleum Geology, 41(1): 67-83.

Poszytek, A., Suchan, J., 2016. A tight gas reservoir in the basinal facies of the Upper Permian Ca1 in the southwestern Zechstein Basin, Poland. Facies, 62(3): 1-13. DOI: 10.1007/s10347-015-0453-5.

Sowiżdżał K., Such P., Leśniak G., Słota-Valim M., 2017. Ocena wpływu właściwości petrofizycznych skał łupkowych na ich efektywność uszczelniania poziomów zbiornikowych i akumulacji złożowych. Nafta-Gaz, 10: 730-738. DOI: 10.18668/ NG.2017.10.02.

Such P., 1997. Nowoczesne metody badania właściwości petrofizycznych skał oraz możliwości zastosowania otrzymanych wyników w badaniach diagenezy. Przegląd Geologiczny, 45(8): 781-784.

Suchan, J., Rożek, R., Hryciuk, A., 2013. Warunki sedymentacji i zróżnicowanie facjalne Wapienia Cechsztyńskiego a zagrożenie gazowe i gazogeodynamiczne w O/ZG „Rudna”. KGHM Polska Miedź S.A. V Konferencja Sedymentologiczna POKOS 5'2013.

Zawisza L., Krause E., Czekański E., Czopek Z., Dąbrowska B., Dąbrowski J., Gruszka A., Kozimor T., Marcinkowski A., Maruta M., Mularczyk A., Piestrzyński A., Przybyła P., Raś B., Wątor L., Wierzbiński K., Wójtowicz K., 2010. Prognoza potencjalnych obszarów akumulacji gazów, ocena gazonośności skał złożowych i otaczających oraz identyfikacja potencjalnych źródeł emisji węglowodorów wraz z drogami ich migracji w części złóż Sieroszowice, Rudna oraz Głogów Głęboki Przemysłowy. Kraków: Stowarzyszenie Naukowe im. S. Staszica.

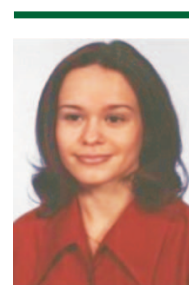

Mgr Małgorzata KANIA

Asystent w Zakładzie Geologii i Geochemii

Instytut Nafty i Gazu - Państwowy Instytut Badawczy ul. Lubicz 25 A

31-503 Kraków

E-mail: malgorzata.kania@inig.pl

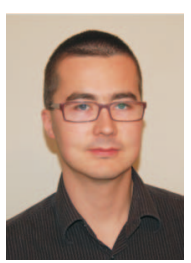

Mgr inż. Marek JANIGA

Asystent w Zakładzie Geologii i Geochemii

Instytut Nafty i Gazu - Państwowy Instytut Badawczy ul. Lubicz $25 \mathrm{~A}$

31-503 Kraków

E-mail: marek.janiga@inig.pl

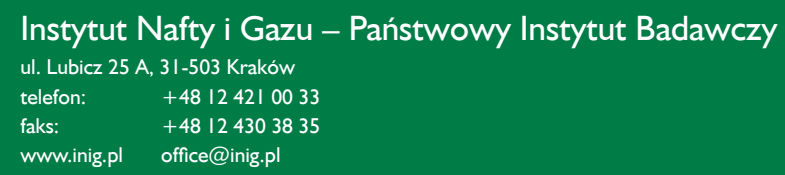

\section{Wiedza w zasiegu Twojej ręki}

\section{Wydawnictwa:}
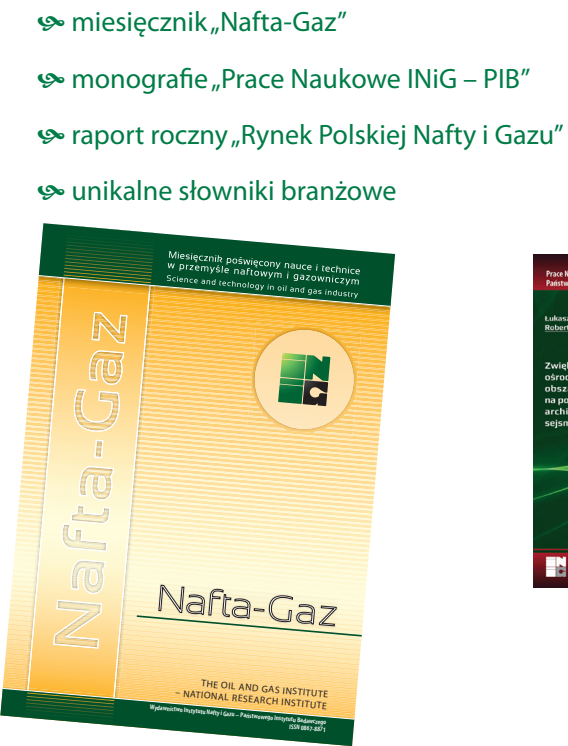

do nabycia w Redakcji Instytutu Nafty i Gazu - Państwowego Instytutu Badawczego e-mailowo: nafta-gaz@inig.pl lub telefonicznie: +48 126177632 